\title{
Identifikasi Cendawan Endofit Menggunakan Teknik Polymerase Chain Reaction
}

\author{
Detection of Endophytic Fungi Using \\ Polymerase Chain Reaction Technique
}

\author{
Tuti Susanti Legiastuti*, Tri Aminingsih \\ Universitas Pakuan, Bogor 16143
}

\begin{abstract}
ABSTRAK
Penyakit keriting kuning yang disebabkan oleh infeksi Begomovirus (Geminiviridae) merupakan salah satu penyakit penting pada tanaman cabai di Indonesia. Eksplorasi cendawan endofit dilakukan sebagai langkah awal untuk mencari agens biokontrol yang potensial menekan penyakit keriting kuning cabai. Cendawan endofit diisolasi dari pertanaman cabai di daerah Sleman, Yogyakarta dan isolat selanjutnya diidentifikasi menggunakan teknik polymerase chain reaction (PCR) dan perunutan DNA. Pita DNA berukuran $\pm 500 \mathrm{pb}$ berhasil diamplifikasi dari 10 isolat cendawan endofit menggunakan pasangan primer ITS1/ITS4, tetapi urutan DNA hanya diperoleh dari 8 isolat. Berdasarkan pada analisis BLASTN diketahui kemiripan masing-masing isolat dengan spesies cendawan pada GenBank, yaitu isolat H1 dengan Pleosporaceae sp. (98\%), isolat H5 dengan Cercospora nicotianae (100\%), isolat H11 dengan Cercospora piaropi (98\%), isolat H16 dengan Guignardia mangiferae (99\%), isolat H17 dengan Geomyces pannorum (95\%), isolat H18 dengan Diaporthe phaseoloru (99\%), isolat K3 dengan Dothideomycete sp. (100\%), dan isolat K10 dengan Alternaria longissima (99\%).
\end{abstract}

Kata kunci: Begomovirus, cabai, perunutan DNA, polymerase chain reaction

\begin{abstract}
Yellow leaf curl disease, caused by a member of Begomovirus (Geminiviridae), is one of important diseases of chilli pepper in Indonesia. Exploration of endophytic fungi was initiated in order to find biological control agents for an alternative control strategies of this disease. Isolates of endophytic fungi were collected from chilli pepper growing area in Sleman, Yogyakarta and further identification using molecular technique involving polymerase chain reaction (PCR) and DNA sequencing was performed. DNA fragments of $\pm 500 \mathrm{bp}$ were successfully amplified from 10 fungal isolates by PCR using primer pair ITS1/ITS4, but only 8 DNA sequences was obtained for further genetic analysis. Based on BLASTN analysis the endophytic fungi were identified as having the highest similarity with Pleosporaceae sp. (98\%) for H1 isolate, Cercospora nicotianae (100\%) for H5 isolate, Cercospora piaropi (98\%) for H11 isolate, Guignardia mangiferae (99\%) for H16 isolate, Geomyces pannorum (95\%) for H17 isolate, Diaporthe phaseoloru (99\%) for H18 isolate, Dothideomycete sp. (100\%) for K3 isolate, and Alternaria longissima (99\%) for K10 isolate.
\end{abstract}

Key words: Begomovirus, chillipepper, DNA sequencing, polymerase chain reaction

*Alamat penulis korespondensi: Program Studi Kimia, Fakultas Matematika dan Ilmu Pengetahuan Alam, Universitas Pakuan, Jalan Pakuan PO Box 452, Bogor 16143

Tel: 0251- 8375547, Faks: 0251- 8375547, Surel: tuti.legiastuti@gmail.com 


\section{PENDAHULUAN}

Endofit adalah mikroorganisme yang mengoloni bagian dalam tanaman tanpa menimbulkan pengaruh yang merugikan pada tanaman inangnya, sebaliknya dapat membantu menginduksi ketahanan tanaman terhadap gangguan biotik maupun abiotik. Setiap spesies tanaman dilaporkan merupakan inang bagi cendawan endofit. Cendawan endofit mempunyai peranan meningkatkan toleransi terhadap kekeringan serta menghambat perkembangan serangga herbivora, cendawan patogen, virus dan nematoda yang menyerang perakaran. Sebagai agens biokontrol cendawan endofit memiliki mekanisme parasitisme, antibiosis, kompetisi nutrisi, dan induksi ketahanan. Cendawan endofit menghasilkan metabolit fungsional yang termasuk dalam kelompok terpenoids, steroids, xanthones, chinones, phenol, isocoumarins, benzopyranones, tetralones, cytochalasines dan enniatines yang berperan sebagai antibakteri, antiviral, dan anticendawan (Suryanarayanan et al. 2009).

Cendawan endofit berpotensi sebagai agens biokontrol karena keberadaan cendawan endofit ini sangat beragam dan berlimpah, dapat ditemukan baik pada tanaman pertanian maupun pada rumput-rumputan. Chaetomium globosum dan Phoma sp. merupakan cendawan endofit yang diisolasi dari tanaman gandum, keduanya dapat menekan keparahan penyakit yang disebabkan Puccinia titricina dan Pyrenophora spp. (Dingle dan McGee 2003; Istifadah dan McGee 2006). Aplikasi cendawan endofit untuk menekan keparahan penyakit pada tanaman kakao yang disebabkan oleh Phytophthora sp. dilaporkan oleh Arnold et al. (2003). Penelitian tentang cendawan endofit serta potensinya sebagai agens biokontrol untuk virus tanaman masih terbatas (Zabalgogeazcoa 2008). Lehtonen et al. (2006) melaporkan aplikasi cendawan endofit dapat mengurangi frekuensi Barley yellow dwarf virus (BYDV) yang menyerang tanaman Lolium pratense.
Dalam rangka mencari agens biokontrol untuk mengendalikan penyakit daun keriting kuning cabai yang disebabkan oleh Begomovirus dilakukan eksplorasi cendawan endofit dari tanaman cabai di daerah endemik penyakit daun keriting kuning cabai di Yogyakarta. Penelitian selanjutnya bertujuan mengidentifikasi cendawan endofit yang diperoleh menggunakan teknik polymerase chain reaction (PCR) yang sudah banyak digunakan sebagai metode identifikasi yang akurat.

\section{BAHAN DAN METODE}

\section{Isolasi Cendawan Endofit}

Sampel daun diambil dari pertanaman cabai dengan insiden penyakit keriting kuning yang tinggi di daerah Sleman, Yogyakarta. Cendawan endofit dari daun cabai diisolasi menggunakan metode Rodrigues (1994). Sterilisasi daun secara bertahap dilakukan sebanyak dua kali menggunakan berturutturut etanol $96 \%$ selama 30 detik, $\mathrm{NaOCl}$ $1 \%$ selama 1 menit, dan etanol $70 \%$ selama 30 detik. Daun cabai kemudian dipotong kecil, diletakkan pada agar-agar cawan potato dextrose agar (PDA), dan diinkubasi pada suhu ruang. Miselium yang tumbuh dari potongan daun, dipindahkan ke agaragar cawan PDA yang baru sampai diperoleh biakan murni. Masing-masing biakan murni cendawan diamati warna dan morfologi koloninya.

\section{Isolasi dan Amplifikasi DNA Cendawan}

Ekstraksi DNA dilakukan berdasarkan pada metode Castillo et al. (1994) yang telah dimodifikasi, yaitu dengan penambahan polyvinylpirolydone (PVP) pada bufer ekstraksi CTAB dan natrium asetat pada tahap pengendapan DNA. Pelet yang diperoleh dicuci dengan $500 \mu \mathrm{L}$ etanol $70 \%$, dikeringkan, kemudian diresuspensi dengan $100 \mu \mathrm{L}$ bufer TE. Suspensi DNA disimpan pada $-20{ }^{\circ} \mathrm{C}$ atau dapat langsung digunakan untuk proses selanjutnya. 
Amplifikasi DNA cendawan menggunakan pasangan primer ITS1 (5' TCCGTAGG TGAACCTGCGG 3') dan ITS4 (5' TCCTCC GCTTATTGATATGC 3'). Reaksi PCR (volume $25 \mu \mathrm{L}$ ) terdiri atas $1 \mu \mathrm{L}$ DNA sampel dengan konsentrasi 25-50 ng $\mu \mathrm{L}^{-1} ; 18.8 \mu \mathrm{L}$ air bebas nuklease; $2.5 \mu \mathrm{L} \mathrm{10x}$ bufer PCR (10 mM $\mathrm{KCl}, 20 \mathrm{mM}$ Tris $\mathrm{HCl} \mathrm{pH} 8.8,10 \mathrm{mM}$ $\left(\mathrm{NH}_{4}\right)_{2} \mathrm{SO}_{4}, 2 \mathrm{mM} \mathrm{MgCl} 2$, dan $0.1 \%$ Triton $\mathrm{X}-100$ ) (Fermentas, USA); $0.5 \mu \mathrm{L}$ dNTP 10 $\mathrm{mM}$ (Fermentas, USA); masing-masing $1 \mu \mathrm{L}$ primer ITS1 dan ITS4 dengan konsentrasi $10 \mu \mathrm{M} ; 0.2 \mu \mathrm{L}$ enzim Taq DNA polimerase rekombinan 5U $\mu \mathrm{L}^{-1}$ (Dream Taq DNA Polymerase Fermentas, USA). Amplifikasi didahului dengan denaturasi awal selama 5 menit pada $94{ }^{\circ} \mathrm{C}$, dilanjutkan sebanyak 35 siklus melalui tiga tahapan meliputi denaturasi selama 1 menit pada $94{ }^{\circ} \mathrm{C}$, penempelan primer (annealing) selama 1 menit pada $55^{\circ} \mathrm{C}$, sintesis selama 2 menit pada $72{ }^{\circ} \mathrm{C}$, pada tahap akhir ditambah 10 menit pada $72{ }^{\circ} \mathrm{C}$. Analisis DNA hasil amplifikasi dilakukan dengan elektroforesis menggunakan gel agarosa $1 \%$ dalam bufer Tris Boric EDTA (TBE 0.5x) dan visualisasi menggunakan sinar UV (Sambrook dan Russel 2001).

\section{Analisis Perunutan DNA}

DNA hasil amplifikasi digunakan untuk tahapan perunutan DNA berdasarkan pada metode dideoxy nucleotide chain termination (Macrogen Inc., Korea Selatan). Hasil perunutan DNA selanjutnya disusun dengan program Bioedit dan dianalisis menggunakan program BLASTN dengan memanfaatkan informasi dari Genbank (http://www.ncbi. nlm.nih.gov).

\section{HASIL}

\section{Morfologi Koloni Cendawan Endofit}

Tiga puluh empat isolat cendawan endofit berhasil diisolasi dari daun cabai (data tidak ditampilkan). Berdasarkan pada pengamatan warna dan morfologi koloni dipilih 10 isolat untuk tahap identifikasi lanjut (Gambar 1). Sebagian besar koloni cendawan berwarna putih pada awal pertumbuhannya, tetapi kemudian berubah warna menjadi keabuan (H0, H1, K3), atau kehitaman (H5, H16), dan ada pula koloni cendawan yang tetap berwarna putih (H11, H12). Beberapa koloni cendawan berwarna abu-abu kehitaman sejak awal pertumbuhan (K10), kuning di bagian tengah (H18), atau putih kusam di bagian tengah (H17). Berdasarkan pada bentuk tepi koloni dapat dibedakan koloni dengan tepi menyebar tidak beraturan dan koloni dengan tepi halus. Beberapa koloni menunjukkan sifat morfologi yang berbeda, di antaranya pola pertumbuhan konsentris (H0, H16), pertumbuhan miselium mengudara (aerial) (H1, K3), tekstur koloni yang tebal (H11, $\mathrm{H} 12, \mathrm{H} 16)$ atau tipis $(\mathrm{H} 1, \mathrm{~K} 3)$.

\section{Amplifikasi dan Perunutan DNA}

Pita DNA cendawan berukuran $\pm 500 \mathrm{pb}$ berhasil teramplifikasi dari 10 isolat cendawan endofit (Gambar 2). Ukuran pita DNA tersebut sesuai dengan yang diharapkan. Hasil perunutan DNA dari 8 isolat cendawan endofit dapat digunakan untuk analisis lanjut karena hasil perunutan DNA dari 2 isolat lainnya (H0 dan H12) menunjukkan elektroferogram yang tidak terpisah dengan baik.

Hasil analisis urutan DNA dari 8 isolat cendawan endofit menunjukkan identitas yang berbeda untuk masing-masing isolat cendawan tersebut dengan tingkat kemiripan $\geq$ 95\% (Tabel 1). Hasil analisis dengan program BLASTN yang digunakan adalah data yang menunjukkan kemiripan yang paling tinggi (>90\% dengan $e$ value 0.0 ) sesuai ketentuan Clavarie dan Notredam (2003). Isolat H1 mempunyai kemiripan dengan Pleosporaceae sp. (98\%), isolat H5 dengan Cercospora nicotianae (100\%), isolat H11 dengan Cercospora piaropi (98\%), isolat H16 dengan Guignardia mangiferae (99\%), isolat H17 dengan Geomyces pannorum (95\%), isolat H18 dengan Diaporthe phaseoloru (99\%), isolat K3 dengan Dothideomycete sp. (100\%), dan isolat K10 dengan Alternaria longissima (99\%). 


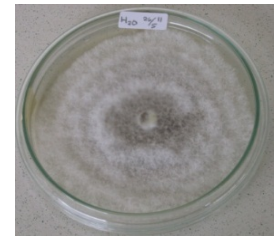

1

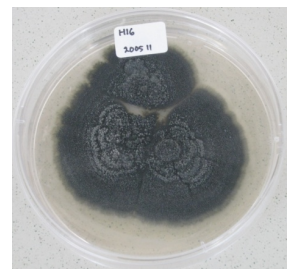

6

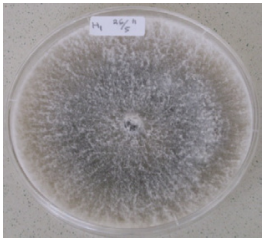

2

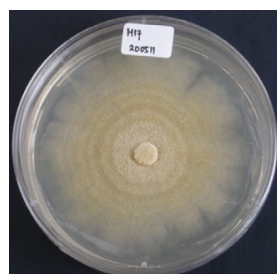

7

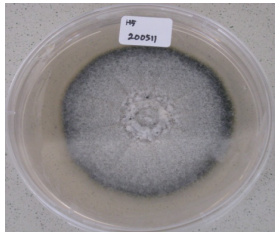

3

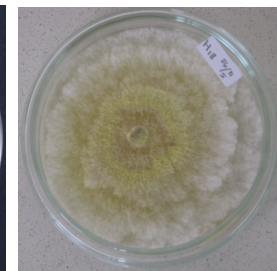

8

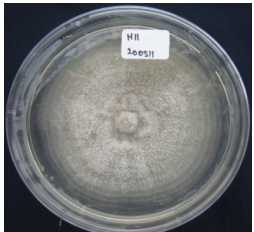

4

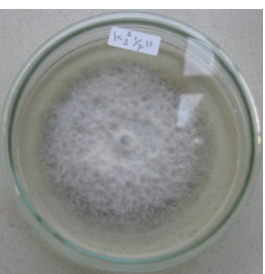

9

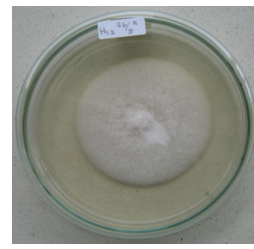

5

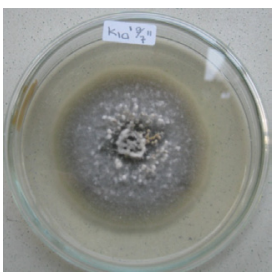

10

Gambar 1 Koloni 10 isolatcendawan endofit asal tanaman cabai yang ditumbuhkan pada medium PDA. Nomor 1-10 berturut-turut ialah isolat H0, H1, H5, H11, H12, H16, H17, H18, K3, dan K10

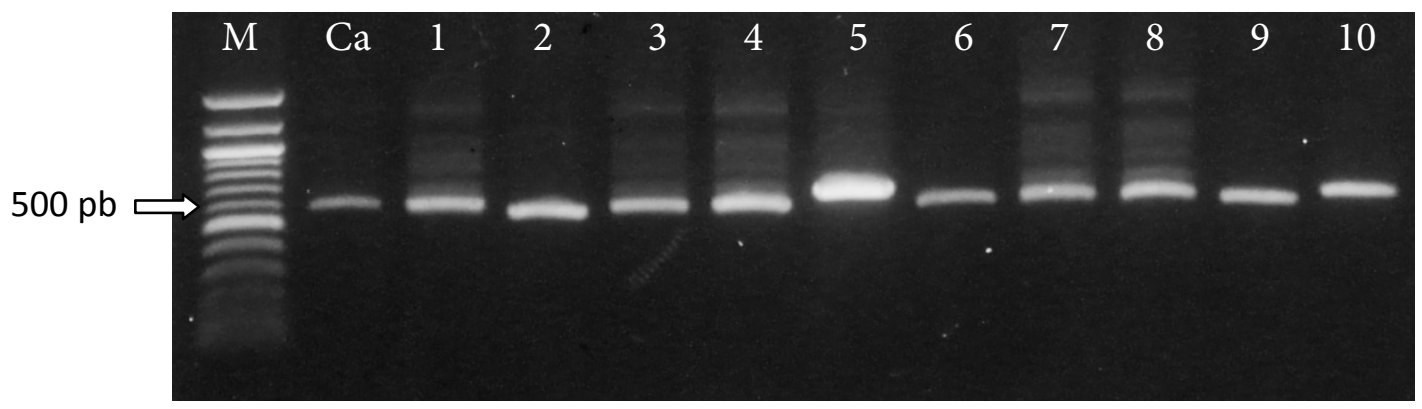

Gambar 2 Hasil amplifikasi DNA cendawan endofit asal tanaman cabai menggunakan pasangan primer ITS1/ITS 4. M, 100 pb DNA ladder (Fermentas); Ca, Colletotrichum acutatum sebagai pembanding; Lajur 1-10 berturut turut isolat $\mathrm{H} 0, \mathrm{H} 1, \mathrm{H} 5, \mathrm{H} 11, \mathrm{H} 12, \mathrm{H} 16, \mathrm{H} 17, \mathrm{H} 18$, K3, dan K10.

Tabel 1 Tingkat kemiripan isolat cendawan endofit asal tanaman cabai berdasarkan pada analisis BLASTN

\begin{tabular}{lclrll}
\hline $\begin{array}{l}\text { Kode } \\
\text { isolat }\end{array}$ & $\begin{array}{c}\text { Panjang } \\
\text { Nukleotida } \\
(\mathrm{pb})\end{array}$ & \multicolumn{1}{c}{ Identitas } & $\begin{array}{c}\text { Kemiripan } \\
(\%)\end{array}$ & $\begin{array}{l}\text { Kode aksesi } \\
\text { GeneBank }\end{array}$ & \multicolumn{1}{c}{$\begin{array}{c}\text { Asal inang/ } \\
\text { Asal geografi }\end{array}$} \\
\hline H1 & 586 & Pleosporaceae & 98 & EF 060411 & $\begin{array}{l}\text { Pleosporaceae sp./Hawaii, USA } \\
\text { H5 }\end{array}$ \\
546 & Cercospora nicotianae & 100 & AF 29230 & Nicotiana tabacum/Tenneessee \\
H11 & 520 & Cercospora piaropi & 98 & HQ902254. & Bunga bakung/Fujian, Cina \\
H16 & 619 & Guignardia mangiferae & 99 & FJ538333.1 & Musa paradisiaca/Thailand \\
H17 & 556 & Geomyces pannorum & 95 & GU222395 & Morinda citrifolia/ India \\
H18 & 556 & Diaporthe phaseolorum & 99 & HM012819 & Mangrove/Thailand \\
K3 & 551 & Dothideomycete sp & 100 & EU680557 & Mocis latipes/Florida, USA \\
K10 & 566 & Alternaria longissima & 99 & AF229489 & Alternaria sp./California, USA \\
\hline
\end{tabular}

\section{PEMBAHASAN}

Endofit telah berhasil diisolasi dari berbagai spesies tanaman, diantaranya dari tanaman berkayu Podocarpaceae, Fagaceae, Winteraceae (Gonthier et al. 2006; Oses et al. 2008), palma (Frohlich et al. 2000), rumput laut (Alva et al. 2002), juga lumut kerak (Li et 
al. 2007). Hernawati et al. (2011) mengisolasi lima cendawan endofit dari tanaman cabai di Bogor. Isolat cendawan endofit lebih banyak diperoleh dari tanaman yang tidak menunjukkan gejala infeksi Begomovirus dibandingkan dengan tanaman yang menunjukkan gejala (data tidak ditampilkan). Delapan isolat cendawan endofit yang digunakan dalam penelitian ini berasal dari tanaman cabai yang tidak menunjukkan gejala infeksi Begomovirus (H0, H1, H5, H11, H12, H16, H17, H18) dan 2 isolat dari tanaman yang menunjukkan gejala infeksi Begomovirus, yaitu daun mosaik dan menguning ( $\mathrm{K} 3$ dan $\mathrm{K} 10$ ). Jumlah dan keragaman endofit sangat ditentukan oleh intensitas pekerjaan eksplorasi yang dilakukan. Hyde dan Soytong (2008) menyimpulkan jumlah dan keragaman endofit ditentukan oleh kemampuan dan ketersediaan waktu untuk mengisolasi endofit pada medium agar-agar; sumber asal tanaman (isolasi dari tanaman asal daerah beriklim sedang akan menghasilkan komunitas endofit berbeda dari daerah tropik atau isolasi dari jaringan tanaman yang berbeda akan menghasilkan komunitas endofit yang berbeda).

Penelitian tentang kelimpahan dan keragaman cendawan endofit memerlukan metode yang tepat terutama dalam identifikasi. Identifikasi cendawan endofit berdasarkan pada morfologi koloni dan spora yang terbentuk sering kali tidak dapat memberikan kepastian identitas suatu isolat. Hal tersebut disebabkan karena morfologi koloni cendawan endofit dapat berubahubah, sebagian cendawan endofit tumbuh sangat lambat dan sering kali tidak terjadi sporulasi (Hyde dan Soytong 2008). Tiga dari 5 isolat cendawan endofit yang diperoleh Hernawati et al. (2011) dapat diidentifikasi berdasarkan pada morfologi koloni dan spora yang terbentuk, sedangkan 2 isolat lainnya merupakan hifa steril sehingga identitasnya hanya dapat diketahui melalui teknik PCR yang dilanjutkan dengan perunutan DNA.

Amplifikasi DNA cendawan dengan teknik PCR sering kali menggunakan pasangan primer ITS1/ITS4 yang akan mengamplifikasi daerah ITS DNA ribosom (rDNA). DNA ribosom (rDNA) adalah daerah penyandi genom untuk komponen RNA ribosom (rRNA). Gen ini banyak digunakan dalam filogenetika, klasifikasi, dan identifikasi untuk cendawan karena sifat keberadaannya yang universal, struktur sekuennya yang konservatif dan terdapat dalam jumlah banyak. Amplifikasi DNA cendawan endofit asal tanaman cabai yang dilanjutkan dengan perunutan nukelotida berhasil mengidentifikasi 8 isolat cendawan endofit. Semua tergolong dalam filum Ascomycota, tetapi berbeda kelas yaitu Dothideomycetes (H1, H5, H12, H16, K3, K10), Leotiomycetes (H17), dan Sordariomycetes (H18). Anggota ketiga kelas cendawan tersebut telah dilaporkan sebagai patogen tanaman, endofit, dan saprob yang hidup pada sisa-sisa tanaman atau di dalam tanah (Zabalgogeazcoa 2008).

Identifikasi cendawan endofit menggunakan teknik PCR dan perunutan DNA memiliki kepekaan yang tinggi, cepat, dan akurat. Identitas cendawan endofit dapat diketahui hingga tingkat spesies berdasarkan pada analisis BLASTN hasil perunutan DNA. Seiring dengan perkembangan biologi molekul, metode ini menjadi pilihan untuk mengidentifikasi, terutama bila identifikasi secara morfometri sulit untuk dilakukan.

\section{UCAPAN TERIMA KASIH}

Terima kasih kepada Damayanti yang membantu dalam pengambilan sampel daun cabai di Sleman, Yogyakarta dan pemurnian isolat-isolat cendawan endofit serta Sri Hendrastuti Hidayat yang menyediakan fasilitas selama pelaksanaan penelitian di Laboratorium Virologi Tumbuhan, Departemen Proteksi Tanaman, Institut Pertanian Bogor.

\section{DAFTAR PUSTAKA}

Alva P, McKenzie EHC, Pointing SB, PenaMuralla R, Hyde KD. 2002. Do sea grasses 
harbour endophytes? Fungal Divers Res Series. 7:167-178.

Arnold AE, Mejia LC, Kyllo D, Rojas EI, Maynard Z, Robbins N, Herre EA. 2003. Fungal endophytes limit pathogen damage in a tropical tree. PNAS USA. 100(26):15649-15654. doi: 10.1073/pnas. 2533483100

Castillo CO, Chalmers KJ, Waugh R, Powell

W. 1994. Detection of genetic diversity and selective gene in coffea using RAPD markers. Theor Appl Genet. 87(8):934940. doi: 10.1007/BF00225787.

Dingle J, McGee PA. 2003. Some endophytic fungi reduce the density of pustules of Puccinia recondita f.sp. tritici in wheat. Mycol Res. 107(3):310-316.

Faeth, SH. 2002. Are endophytic fungi defensive plant mutualists? Oikos. 98(1):25-36. doi: 10.1034/j.1600-0706.2002.980103.x

Franzluebbers AJ, Nazih N, Stuedemann JA, Fuhrmann JJ, Schomberg HH, Hartel PG. 1999. Soil carbon and nitrogen poll under low- and high- endophyte infected tall fescue. Soil Sci AM J. 63(6):1687-1694

Frohlich J, Hyde KD, Petrini O. 2000. Endophytic fungi associated with palms. Mycol Res. 104(10):1202-1212.

Hernawati H, Wiyono S, Santoso S. 2011. Leaf endophytic fungi of chili (Capsicum annuum) and their role in the protection against Aphis gossypii (Homoptera: Aphididae). Biodiversitas. 12(4):187-191.

Hyde KD, Soytong K. 2008. The fungal endophyte dilemma. Fungal Divers. 33:163-173.
Istifadah N, McGee PA. 2006. Endophytic Chaetomium globosum reduces development of tan spot in wheat caused by Pyrenophora triticirepentis. Aus Plant Path. 35(4):411-418. doi.:/10.1071/AP06 038

Lehtonen PT, Helander M, Siddiqui SA, Lehto K, Saikkonen K. 2006. Endophytic fungus decreases plant virus infections in meadow ryegrass (Lolium pratense). Biol Lett. 2(4):620-623. doi: 10.1098/rsbl. 2006.0499 .

Li WC, Zhou J, Guo SY, Guo LD. 2007. Endophytic fungi associated with lichens in Baihua mountain of Beijing China. Fungal Divers. 25:69-80.

Oses R, Valenzuela S, Freer J, Sanfuentes E, Rodriguez J. 2008. Fungal endophytes in xylem of healthy chilean trees and their possible role in early wood decay. Fungal Divers. 33:77-86.

Rodrigues KF. 1994. The foliar fungal endophytes of the Amazonian palm Euterpe oleracea. Mycologia. 86(3):376-385.

Sambrook J, Russel DW. 2001. Molecular Cloning a Laboratory Manual. Ed ke-3. New York (US): Cold Spring Harbor Laboratory Pr.

Suryanarayanan TS, Thirunavukkarasu N, Govindarajulu MB, Sasse F, Jansen R, Murali TS. 2009. Fungal endophytes and bioprospecting. Fungal Biol Rev. 23(12):9-19. doi: 10.1016/j.fbr.2009.07.001

Zabalgogeazcoa I. 2008. Fungal endophytes and their interaction with plant pathogens. Spanish J Agric Res. 6:138-146. 